as educators throughout the country already cooperate with their friends at the Board of Educatior, whom, more and more, they look upon as colleagues who share their interests and spend themselves in the same service. Thus will every walk in life come to be regarded as a branch of public service. Just as the Board of Education is aided by the Teachers' Registration Council as an advisory body, so the joint standing industrial councils that are being established according to the Whitley Committee's report may, before long, become advisory bodies to the new Ministries of Employment, Production, and Supplies.

The reform of the machinery of Government proposed by the Committee would, moreover, render it possible for all the higher officers of the ten Departments to be experts in their respective professions. They would then be better able to work intelligently for a definite purpose than is possible for mere administrators of miscellaneous regulations. We have advisedly stated that all the higher staff of each of the new offices should be expert; for the Committee, taking the Board of Education as a model, in many respects, of what the new Departments should be, would apparently be content with expertness on the part of the inspectorate alone. We believe, on the contrary, that the top men inside the new Whitehall offices should be encouraged to spend part of their time outside the office, acquiring intimate personal knowledge of the activities with which their Department is concerned, and of the men who are chiefly responsible for these activities in the country. Insisting, however, as we do, that the Civil Servants of the reformed Departments shall possess expert knowledge, we are far from underestimating the extreme importance of continuing to select only the ablest men for work of the higher division. But we maintain that, unless within a few years of their appointment they show promise of becoming expert in the work of their particular Department, they should be retired from the Service. Able, detached, and serene has been the typical Civil Servant of the past. No less able must be the Civil Servant of the future. Strenuous intellectual discipline must continue to be regarded as a necessary preliminary to entering the higher division of the Civil Service. But, instead of being detached, he must make his work his hobby. He must know his job and love it. "Without passion," said Lord Haldane years ago to the students of Edinburgh University, "nothing great is, or ever has been, accomplished."

Lord Haldane's Committee recognises that a more expert Civil Service would require increased Parliamentary control if the danger of bureaucracy is to be avoided. It suggests that Parliament might retain the necessary control by appointing a series of standing committees, each concerned with the activities of one of the ten Departments. It should, however, be borne in mind that neither this nor any other means of Parliamentary control will be satisfactory unless the personnel of the House of Commons is equal NO. 2579 , VOL. IO3] to these new duties. ${ }^{2}$ In this connection it is well worth considering whether at least half the members of the House of Commons, instead of only the university representatives, should not be elected on an occupational, instead of on a residential, franchise. As a rule, people engaged in the same branch of national service have in these days far more in common with one another, and would take far more interest in a member who represented them in Parliament than the miscellaneous folk whose only link is that they chance to reside in the same neighbourhood.

Lord Haldane's Committee has little to say upon the application of its principle to local government. Since the destruction of School Boards in 1902, most of the functions of local government have been performed by county, county borough, and borough councils, the concern of which is not with any particular group of services, but with particular groups of people. We are far from desiring the resuscitation of the old School Boards, or the establishment of small ad hoc bodies for the local control of other services. But we would point out that subdivision of local responsibility for every form of national service, according to borough boundaries, and sometimes according to narrower boundaries still, has an injurious effect upon the efficiency of some of these services quite comparable with that of the present subdivision of responsibility among the different offices in Whitehall. Particularly is this the case with education. The local organisation of education cannot be satisfactorily effected by an authority that is responsible for part only of one complete organism centred in the local university or-as in the case of Manchester and Liverpool -universities. Responsibility for the administration of education throughout such an area might well be entrusted to a department of each of some ten or twelve provincial governments that would be the supreme authorities for the manifold activities of the various minor local authorities in their respective areas. In short, it is as important to apply the principle of Lord Haldane's Committee to local government as to central government. But it will be possible to do so only by enlarging the areas for which the local governments are responsible.

It remains to add that the transition from war to peace, which renders the reorganisation of some of the machinery of Government inevitable, is the proper time for making the further changes recommended by Lord Haldane's Committee. Their need is urgent.

\section{SIR E. C. STIRLING, C.M.G., F.R.S.}

THE death on March 20, in South Australia, of 1 Sir Edward Charles Stirling, professor of physiology at the University of Adelaide, and director of the South Australian Museum, deprives Adelaide of one of its best-known figures.

Sir Edward was the eldest son of the Hon.

2 An article in the Times of January 21 , corrected on January 24 , has pointed out that the new House of Commons contains not one Fellow of the Royal Society who is not either a university member (Sir Joseph Larmor and Sir Watson Cheyne) or a Privy Councillor (Mr. Balfour). 
Edward Stirling. He was born in 1848 , and his early education was obtained at St. Peter's College, Adelaide. Later he went to Trinity College, Cambridge, where he took honours in natural science. He completed his medical education at St. George's Hospital, where he later occupied the positions of house surgeon, assistant surgeon, teacher of operative surgery, and lecturer in physiology. He became a F.R.C.S. in 1874. In 1877 he married the eldest daughter of the late Joseph Gilbert, of Pewsey Vale, and four years later returned to Australia. Sir Edward's activities in Adelaide, where he spent the remainder of his life, were manifold. For a time he practised surgery, and became a surgeon at the Adelaide Hospital and lecturer in surgery at the University. From $\mathrm{I} 883$ to $\mathrm{x} 886$ he was member for North Adelaide in the House of Assembly. In 1887 he presided over the Section of Surgery at the Second Intercolonial Medical Congress. In I889 he was president of the South Australia branch of the British Medical Association, and in the following year held the presidency of the Royal Society of South Australia.

Most of Sir Edward's scientific work was pub. lished in the period $1888-1902$, during which time he wrote several interesting articles for NATURE. His interests were many, and he made important contributions to science in zoology, palæontology, and anthropology. His best-known work was on the marsupial mole (Notoryctes typhlops) (1888), on the anatomy of the female organs of generation of the kangaroo ( 1889 ), and various important observations on remains found at Lake Callabonna, which were published between 1893 and 1902 , and concerned Diprotodon, Genyornis newtoni, and Phascolonus gigas. In 1894 he accompanied as ethnologist the Horn Scientific Exploration Expedition to Central Australia. $\mathrm{He}$ was made a fellow of the Royal Society in r893, created C.M.G. in the same year, and for his services to science received a gold medal from the Queen of Holland. He was knighted in 1917.

Among the numerous institutions in Adelaide with which Sir Edward was associated there are two that owe much to his energy and ability - the University, where he was lecturer, and afterwards professor, of physiology, and the South Australian Museum, of which he was for many years director. His death will be deeply felt by a wide circle of people who knew him as a vigorous and kindly personality and as a staunch and loyal friend.

C. H. K.

\section{NOTES.}

The Berliner Tageblatt announces that Herr Hans Bredow, an engineer who was formerly a director of the Telefunken Co., has been appointed DirectorGeneral of the Imperial Postal Department, and at the same time it directs attention to the fact that this is, so far as it knows, the first occasion on which a position held in Germany, as a rule, by lawyers and bureaucrats has been filled by the appointment of an engineer. Whilst it is true that since the institution of the Reichspostamt, on January $\mathrm{I}, 1880$, as the NO. 2579, VOL. IO3]
Imperial Department responsible for posts and telegraphs no engineer has occupied the chief administrative position of Secretary of State (the former title of the permanent head of the Department), on the other hand it has to be borne in mind that technically trained men have, from the earliest days of telegraphy in Germany, held important administrative posts in the Telegraph Department. For instance, the members of the Commission for the Administration of the State Telegraphs, appointed in Prussia in March, 1849 , to carry on the telegraph services, consisted of an artillery colonel as chairman, and of an engineer and a postal inspector. In later times many of the important administrative posts in the Reichspostamt have always been held by technically trained men. It can be said generally that on the continent of Europe there has at all times existed a greater appreciation of the technically trained man in the public services than is the case in this country. Many instances could be quoted of engineers holding, on the Continent, the chief administrative positions in the public Departments, such as railways, posts and telegraphs, etc. wherein the work is largely of a technical nature. The example of foreign countries could in this respect be followed with great advantage to the public services in this country.

THE rumours for some time current that Sir Robert Morant was to take the chief post at the new Ministry of Health have proved to be correct. Taking advantage of the approaching retirement of Sir Horace Monro, Permanent Secretary to the Local Government Board, Dr. Addison has appointed Sir Robert Morant an additional Secretary to that Board, and has designated him First Secretary of the Ministry of Health, when formed. Secretary to the Board of Education when the changes rendered necessary by the introduction of school medical inspection were made, and first chairman of the National Health Insurance Commission, Sir Robert Morant seems fated to be called upon to play a prominent part when organisation or reorganisation is needed. That he is well fitted for the task is certain. There are, however, other advantages than those arising from his own qualifications attending the appointment of Sir Robert Morant. Associated with him in his work he is to have Sir George Newman as Chief Medical Officer and $\mathrm{Mr}$. John Anderson as Second Secretary. Both these gentlemen have worked with Sir Robert Morant before, Sir George Newman at the Board of Education, where he was Medical Officer, and Mr. Anderson at the Insurance Commission, where he acted as secretary. It was inevitable, no doubt, that the chairman and secretary of the National Health Insurance Commission and the Medical Officer of the Board of Education should be accommodated at the Ministry of Health, but it is fortunate for Dr. Addison that the holders of these positions should be such men as those named.

THE number of clinical themometers tested at the National Physical Laboratory since the introduction of the Clinical Thermometer Order of October last has this week reached the total of half a million. The equipment for carrying out this work at $T$ eddington has been increased to such an extent that the number of instruments tested per week is considerably in excess of those deait with in any year under the older conditions for the certification of clinical thermometers. At the present time it is found that the number of clinical thermometers which do not comply with the provisions of the Order amounts to about 4 per cent. of the total received. The proportion, however, varies greatly for the different makers; for one firm, the output of which is large, the average 